\title{
NAGY ELŐTOLÁSÚ ESZTERGÁLÁS: NAGYOLÁS ÉS SIMÍTÁS UGYANAZON LAPKÁVAL?
}

\section{HIGH FEED TURNING: ROUGHING AND FINISHING WITH THE SAME INSERT?}

\author{
Ráczi Viktor ${ }^{1}$, Huszák Csenge ${ }^{2}$, Sipos Sándor ${ }^{3}$ \\ Óbudai Egyetem, BGK, Anyag és Gyártástudományi Intézet, Budapest, Magyarország \\ ${ }^{1}$ raczi.viktor@bgk.uni-obuda.hu \\ ${ }^{2}$ huszak.csnger@bgk.uni-obuda.hu \\ ${ }^{3}$ sipos.sandor@bgk.uni-obuda.hu
}

\begin{abstract}
In the last couple of years tools, that make multi-directional machining possible, have revolutionized turning operations. The chip removal of high feed roughing and finishing inserts are so special, that new formulas have to be introduced instead of the usual ones. In this article the results of the tests is summarised and a proposal is made about the force load of multi-directional insert and the description, analizes and estimation of surface roughness.
\end{abstract}

Keywords: multi-directional turning, chip development, force effects, microgeometry.

\section{Összefoglalás}

Az utóbbi években megjelent, többirányú megmunkálást lehetővé tevő szerszámok forradalmasították az esztergálást. A nagy előtolású, nagyolásra és simításra szolgáló lapkák forgácsleválasztása annyira különleges, hogy az eddig megszokott képletetek helyett újakat kell bevezetni. Jelent tanulmány a vizsgálatok eredményeit összegzi, és javaslatot tesz a többirányban alkalmazható lapkák erőigényének, valamint az előállított felületek érdességének leírására, elemzésére és számítására.

Kulcsszavak: többirányú esztergálás, forgácsképződés, erőhatások, mikrogeometria.

\section{Bevezetés}

Gyorsabban, olcsóbban, pontosabban - minden iparvállalat ezekkel a nem túl egyszerűen összeegyeztethető kihívásokkal szembesül a napi tevékenysége során. Mindehhez társulnak a folyamatbiztonsággal és a környezetvédelemmel kapcsolatos, egyre szigorodó elvárások is. A nagy előtolással végzett, többirányú esztergálást (MDHFT - multi-direntional high feed turning) az az igény hozta létre, hogy a bonyolult alkatrész-konfigurációkat kevesebb szerszám felhasználásával lehessen gyártani. Az új elven (PrimeTurningTM) működő szerszámokról már több publikációnk készült [1, 2]. Jelen tanulmány a vizsgálatok eredményeit összegzi, és javaslatot tesz a többirányban alkalmazható lapkák erőigényének, valamint az előállított felületek érdességének leírására, elemzésére és számítására.

\section{Felületképzés PrimeTurningTM szer- számokkal}

A CoroTurn Prime „B” típusú szerszámok elsősorban hossz- és keresztirányban végzett, illetőleg kis hajlásszögű alakos (elsősorban kúpos) felületek megmunkálására szolgálnak. A szerszám élgeometriai sajátossága, hogy az előtolás iránya nagyoláskor ellenkező, mint simítás esetén. Ez a tény nem kizárólag az élek helyzetét és funkcióját változtatja meg, de a nagy előtolással végzett esztergálás módosítja a felületképzés jellegét és a forgácsleválasztása folyamatát (forgácsképződés, erőhatások stb.), sőt a felület létrehozása közben 
átalakul a szerszám kinematikai nyoma is. A szakirodalomban közölt képletek a felsorolt jelenségeket nem írják le, hátráltatva ezzel az eljárás szélesebb körü elterjedését is.

Az újszerű szerszám tanulmányozására kísérletsorozatot hajtottunk végre egy CR-25BR-2525-11 jelü késtartó és a kompatibilis CP-B1108-M5 4325 jelzésü lapka alkalmazásával. A tesztekhez $\phi 60 \times 160 \mathrm{~mm}$ méretű, $11 \mathrm{SMn} 30+\mathrm{C}$ anyagjelü, HB150-155 keménységű automataacél próbatesteket használtunk. A vizsgálatokat BNC1840 jelű, Dugard Eagle gyártmányú CNC-esztergán végeztünk, környezetbarát száraz forgácsolással.

A gép és a szerszám lehetőségeit is figyelembe véve állandó forgácsolósebességgel $\left(v_{c}=250 \mathrm{~m} / \mathrm{min}\right.$ )teszteltünk. A kísérlettervezést is felhasználva tízféle kombinációval esztergáltunk: a fogásmélységet három, az előtolás pedig négy szinten változtattuk. Nagyoláskor $f=0,3 \ldots 1,2$, simításkor pedig $f=0,2 \ldots 0,6 \mathrm{~mm}$ határokat választottunk. A szokásos kialakítású szerszámokhoz viszonyítva (különösen az utóbbiak) közel kétszeres értékek, ami nagyfokú termelékenység-növekedéssel ját. Ez különösen az autóipari divízióban jelent előnyt, hiszen nagyszériás termelésnél minden megtakarított másodpercnek jelentősége van.

\subsection{Forgácsképződési sajátosságok}

$\mathrm{Az}$ alkalmazott lapka geometriai sajátosságai az éleket alkotó kontúr pontjainak megfelelő sürűségü (pl. $1 \mu \mathrm{m}$-es) letapogatásával (profilprojektor: Mitutoyo PJ-H3000F) és modellezéséből (szoftver: Mitutoyo V-COSMOS 2.4 és Catia P3 V5R21) derültek ki. Megjegyezzük, hogy az ismertetőben [3] szereplő megadott értékektől eltéréseket tapasztaltunk.

Nagyoláskor a lapka főéle két, különböző (25 és $5^{\circ}$ ) élszögű részből áll, amelyet nagyméretű rádiusz köt össze. A hagyományos értelemben vett csúcssugár szintén kétféle szögű mellékélben folytatódik. Méréseink szerint a csúcsszög EPSR $=84^{\circ}$, a lapka teljes csúcsszöge $40^{\circ}$, a csúcssugár pedig REPS = 0,6 mm. Ezen sajátosságok a leválasztás szempontjából nagyoláskor meghatározóak: a képződő fogács vastagsága nagyon kicsiny, viszont igen nagy a szélessége. Az 1. ábra a lapka mért geometriai adatait, a forgács elméleti keresztmetszetét és egy leválasztott forgács alakját mutatja be.

Simításkor a szerszám élei - az ellentétes előtolási irány miatt - felcserélődnek és úgy működnek, mint egy CNMG kialakításba „oltott” VNMG jelzésű lapka. Ennek jellemzői: főélszög KAPR=93' mellékél szöge MCEA=2,50, a csúcssugár (termé- szetesen) változatlan marad. Ennek következében a leválasztott forgács keresztmetszete nem tér el a megszokottól (2. ábra).

A leválasztott forgácsok tablóit a 3. ábra szemlélteti. Nagyoláskor 10 esetből hétben kedvezően tört forgács vált le (3a. ábra). A legnagyobb (f > $1 \mathrm{~mm}$ ) előtolások beállításakor már veszélyesen tekeredő, gubancos folyóforgács keletkezett, azonban ezt "megfékezte” a CNC-gép burkolata. A forgács feldarabolásának hatékonyságát az M5 jelzésű forgácstörő egyedi alakzata okozza: mélyen belenyomódik az anyagba, pótlólagos alakváltozásra és a forgács szélességének csökkenésére kényszeríti az éppen leváló anyagot [1].

A simításkor leválasztott forgácsok tablója (3b. ábra) egészen más képet mutat. A szokásosnál lényegesen nagyobb előtolásoknál 0,23...0,9 $\mathrm{mm}^{2}$ határok között alakult a forgácskeresztmetszet. A 2. ábra szerint sokkal „zömökebb” forgácsok keletkeztek, amelyek a törésre jobban reagáló, szétszóródó forgácsok formájában távoztak.



1. ábra. A CoroTurn „B” lapka sajátosságai nagyoláskor

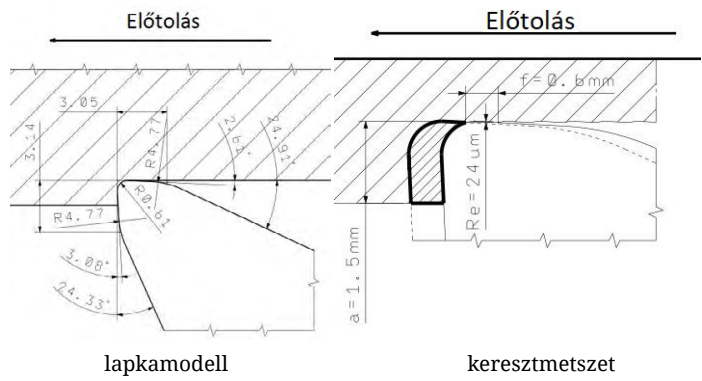

2. ábra. A CoroTurn „B” lapka sajátosságai simításkor

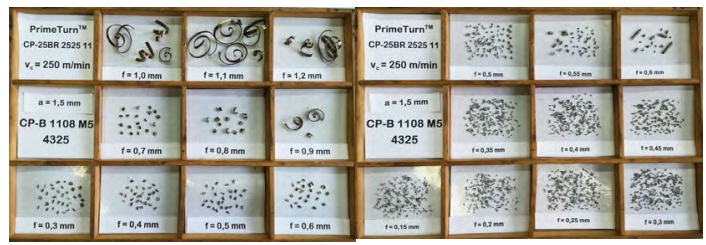

a) nagyolás

b) simítás

3. ábra. $A$ különböző üzemmódok forgácstablói $\left(v_{c}=250 \mathrm{~m} / \mathrm{min} ; a=1,5 \mathrm{~mm}\right)$ 


\subsection{Forgácsolási erőhatások}

Az esztergálás erőkomponenseit KISTLER 9021A típusú berendezéssel mértük és Dynoware szoftverrel értékeltük ki. Az $F_{c}, F_{f}$ és $F_{p}$ erőösszetevőket egyetlen sebességen és fogásmélységen hasonlítottuk össze, ezért a szokásos hatványfüggvény-modell a következő:

$$
F_{j k}=C_{F j k} \cdot f^{x_{F j}}[N]
$$

ahol a $j$ index az erőkomponensre, a $k$ index pedig a nagyolásra/simításra utal. A modellek szorossága azt jelzi, hogy a mért és számított értékek eltérése igen csekély. A 4. ábra a kapott eredményeket szemlélteti.

A 4 a. ábrán jól látható, hogy a nagyoláskor ébredő $F_{c}$ forgácsolóerő átlagosan kb. 10\%-kal nagyobb, mint a simításnál fellépő. Ennek magyarázata a forgács alakjában keresendő és a munkadarab-szerszámél elnyújtott érintkezésével függ össze, a kis forgácsvastagság pedig a fajlagos forgácsolóerő lényeges növekedését eredményezi. Tesztjeinkből az is kiderült, hogy a növelt ( $f>0,9 \mathrm{~mm}$ ) előtolású nagyolás már jelentős $P_{c}$ forgácsolási teljesítményt igényelt. Más okokra vezethető vissza az előtolási erőkomponens $\left(F_{f}\right)$ mért (és egyfaktoros hatványfüggvénnyel) modellezett értéksorozata. Nagyoláskor a kis értékű főélszög csekély erőt igényel, míg simításkor a szerszám nagy főélszöggel forgácsol ugyan (lásd 2. ábra), de kis előtolással, ami - az elmélettel megegyezően - megnövekedett erőhatást vált ki.

Ugyanazzal a szerszámmal végzett nagyolás és simítás esetén fontos szempont a megfelelő pontosság elérése. A munkadarab méretviszonyaitól (átmérőméret és/vagy karcsúság) függően a forgácsoláskor ébredő erőhatások méret- és/vagy alakhibát okoznak. A legnagyobb erőösszetevő az Fc forgácsolóerő, amely azonban csak másodrendü hibát okoz. A fogásmélység irányába fellépő $F_{p}$ passzív erőkomponens elsőrendü hibához vezet.

A 4b. ábra a passzív erőhatást szemlélteti nagyolás és simítás esetén ( $a z F_{c}$ erőhatást csak összehasonlításként tüntettük fel). A szokatlanul kis fóélszög következtében nagyoláskor az $F_{p}$ fele-kéthar-

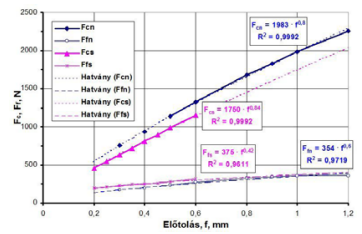

a) aktív erőkomponensek

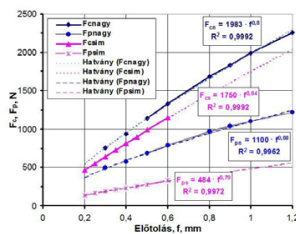

b) passzív erőhatás
4. ábra. A nagyoláskor és simitáskor mér erőkomponensek $\left(v_{c}=250 \mathrm{~m} / \mathrm{min} ; a=1,5 \mathrm{~mm}\right)$ mada az $F_{c}$-nek, ezért karcsú daraboknál jelentős, akár néhány századmilliméteres alakhiba („,hordósság”) is keletkezhet [1]. Az élek felcserélődése és a szögek megváltozása miatt simításkor a passzív erő lecsökken (mindössze 30 \%-a a forgácsolóerőnek), ezért a keletkező alakhiba nem számottevő.

\section{Mikrogeometriai sajátosságok}

Ebben a cikkben a felületminőség mikrogeometriai vonatkozásairól lesz szó, a rétegtulajdonságok egyes elemeire nem térünk ki. Az esztergált felületek (szürt profiljának) $W_{t}$ hullámossági értékeit az [1] irodalom tartalmazza, ezért a továbbiakban a nagyoláskor és simításkor kialakuló felületi profil érdességének elemzésére fókuszálunk.

A vizsgálatokat Perthometer PRK Concept-2D/3D felületvizsgáló nagyműszeren végeztük, a jellemző érdességi paramétereket MarSurf XCR-20 szoftverrel határoztuk meg. Minden egyes adatbeállításról három-három érdességi profilt vettünk fel és értékeltük ki, ezért a következő diagramok átlagos értékeket tartalmaznak.

A megmunkált felületek jellemzése a hazai gyakorlatban általában az érdesség magassági jellemezői, főleg az átlagos érdesség $\left(R_{a}\right)$ és az egyenetlenség-magasság $\left(R_{z}\right)$ megadásával történik. Bár az $R_{a}$ jóval elterjedtebb (mert a felület különböző mért szakaszain közel állandó értékü lehet), azonban nem tuja megmutatni az egyes felületi profilok közötti jellegzetes, akár lényegesnek mutatkozó különbségeket [4]. Vizsgálatainknál ezért a készített profil jellemzői jobban kifejezni képes egyenetlenség-magasság elemzésére koncentráltunk. Ezen paramétert egyre elterjedtebben használják az autó- és repülőgépgyártó ipar beszállítói szegmensében, illetve a formaszerszámgyártásban.

$\mathrm{Az} 5$. ábra a nagyolás és a simítás esetén mért $R z$ értékeket mutatja, feltüntetve az általunk már korábban [1] javasolt,

$$
R z=A \cdot f^{2}+B \cdot f+C[\mu m]
$$

alakú érdességmodellt, sőt, az elméleti érdesség (Relm) számolt adatait is. Az ábrából megállapítható, hogy a Bauer-féle (klasszikus)

$R_{\text {elm }} \approx 125 \cdot f^{2} / \operatorname{REPS}[\mu \mathrm{m}]$

formula nem hozható kapcsolatba a méréssel meghatározott $R_{z}$ adataival. A (2) egyenlet $\boldsymbol{B} \cdot \boldsymbol{f}$ lineáris tagja azt a forgácsoláselméletei tényt fejezi ki, hogy ebben az esetben a mellékélnek is meghatározó szerepe van az esztergált felületi profil kialakításában (az REPS csúcssugár mellett).

Nagyoláskor igen szoros kapcsolat figyelhető meg a mért $R_{z}$ és a (2) modellel számítható érdességadatok között. Simításkor ez a függvény- 
kapcsolat ugyan gyengébb, azonban az egyenetlenség-magasság - a nagy beállított előtolásoktól szinte teljesen függetlenül - kedvezően kis, $R_{z}=4 \mu \mathrm{m}$ körüli értékeket ad.

Az $R_{z}$ diagramvonalak alakulásából az is jól látható, hogy a $B$ jelü lapkával esztergálva mind nagyoláskor, mind pedig simításkor meglepően széles optimális előtolás-tartományok határozhatóak meg, amelyek beállításakor minimális érdesség érhető el. Ennek oka a szerszámélek speciális kialakításában keresendők.

A modell konstansaiból kiszámítható $\left(\mathrm{f}_{\mathrm{opt}}=-\mathrm{B} / 2 \mathrm{~A}\right)$ a legkedvezőbb előtolási értéke, amely nagyoláskor $\mathrm{f}=0,67 \mathrm{~mm}$, simításkor pedig $\mathrm{f}=0,43 \mathrm{~mm}$.

Az alkatrészgyártásban többnyire csak egyetlen paramétert $\left(R_{a}\right.$ vagy $\left.R_{z}\right)$ használnak az esztergált felületek jellemzésére. Az $R_{z}-R_{a}$ közötti átszámításra az elmúlt hat évtizedben az $R_{z}=4 \times R_{a}$ közelítés szolgált szakmai alapul. Ez az arány azonban korlátozott érvényességü és csak nagyolás körülmények között elfogadható. Nem alkalmazható viszont félsimítási, simítási és finomesztergálási feltételekre [4].

A 6. ábra a tesztvizsgálatok során mért $R_{z} / R_{a}$ arány értékeit mutatja. Megfigyelhető, hogy mindkét irányban végzett esztergálásnál és minden előtolásérték beállításakor négynél lényegesen nagyobb az $R_{z} / R_{a}$ viszonyszám. Különösen meglepő, hogy nagyolási üzemmódban (f >> 0,3 mm) is a „misztikus 4” szorzószámot meghaladó az arány. Ez szintén a szerszámél speciális kialakításának a következménye.

Jelen cikkben - terjedelmi okok miatt - nem térhetünk ki azokra az eredményeinkre, amelyekben az esztergált felületek egyedi profilját megfelelően jellemző paraméter-együttest hoztunk létre. Ez egyrészt az általánosan használt érdességei adatokra ( $\left.R_{a}, R_{z}, R_{p}, R_{v}\right)$, másrészt a profil statisztikai paramétereire $\left(R_{s k}, R_{k}, R_{M r}\right)$ épül. Ezekkel a mért adatokkal nemcsak a profil jelenlegi állapotát tudjuk az eddigieknél jóval részletesebben jellemezni, hanem következtetni tudunk az alkat-


5. ábra. $A z$ érdességi 6. ábra. $A z \quad R_{z} / R_{a}$ arány jellemzők alakulása $\left(v_{c}=\right.$ $250 \mathrm{~m} / \mathrm{min} ; a=1,5 \mathrm{~mm}$ ) alakulása $\left(v_{c}=250 \mathrm{~m} /\right.$ $\min ; a=1,5 \mathrm{~mm}$ ) rész felületének jövőbeni, üzemszerű viselkedésére (pl. tartósság, kopás stb.) is [4].

\section{4. Összefoglalás, következtetések}

A jelentős innovációk és az új elveken működő szerszámok csak akkor terjedhetnek el igazán, ha a piacra kerülésüket számos kísérleti és ipari eredmény támasztja alá. Különösen igaz ez az előzőekben vizsgált $B$ típusú szerszámra, amelynek alkalmazhatóságára kevés a felhasználók számára rendelkezésre álló ismeretanyag és tapasztalat. Jelen cikkben azokat a sajátosságokat elemeztük, amelyek a kétféle előtolási irányban, kétfajta üzemmódban (nagyolás és simítás) végzett hoszszesztergálás felületképzését jellemzik.

Mérésekkel kimutattuk, hogy (a sajátságos szerszámgeometria következtében) nagyoláskor és simításkor az élek szerepe felcserélődik, ennek következménye az egyedi forgácsleválasztás. Az élek helyzete és élszögek nagysága döntően befolyásolja a fellépő erőhatásokat és a megmunkált felületen kialakuló érdességnyomokat is. Az $F_{c} F_{f}$ és $F_{p}$ erőösszetevők leírására az ismert hatványfüggvény-modelleket alkalmaztuk. A szokatlanul kis főélszög miatt a passzív erőkomponens nagyoláskor megnövekszik, amely tengelymetszeti alakhibához (hordósság) vezet.

A nagyolási és simítási technológia biztonságosabb tervezhetősége érdekében közelítésként hoztuk létre a (2) $R_{z}$-formulát. Hangsúlyozzuk azonban, hogy a megmunkált felületeket lehetetlen egyetlen „univerzális”, a vizsgált felület állapotát minden szempontból jellemző mérőszámmal leírni. Vizsgálni kell a paraméterek viszonyát $\left(R_{p} / R_{z}\right.$ stb.), az $R_{s k}-R_{k u}$ paraméterkettőssel leírt ún. topológiai térképet, a profil hordozóképességét, stb.

Ezekről a későbbiekben fogunk beszámolni, csakúgy, mint a munkadarab anyagminőségek szélesebb körét (nemesített és korrózióálló acélok, HRSA anyagok stb.) érintő vizsgálatok eredményeiről.

\section{Szakirodalmi hivatkozások}

[1] Ráczi V., Farkas, G., Sipos, S.: Chip removal specialities in multi-directional turning. Műszaki Tudományos Közlemények 9. (2018) 207-210.

[2] Farkas G., Sipos S., Ráczi V.: A felületképzés elemzése többirányú esztergáláskor. Int. Eng. Symp. at Banki, Óbuda University, 21.11.2018. Section I.

[3] New definitions of Turning SANDVIK Coromant (offitional ppt), 2017. 28 slides

[4] Palásti-Kovács B., Sipos S., Biró Sz.: The Mysteries of the Surface. First Part: The Characteristic Features of the Microgeometry of the Machined Surface, Acta Polytechnica Hungarica, 11/5. 5-24. https://doi.org/10.1270000/APH11.05.2014.05.1 